UDC 576. 522: 612.128

\title{
Lys-plasminogen stimulates vitronectin exposure on the platelet surface
}

\author{
D. D. Zhernossekov, Y. M. Roka-Moiia, A. A. Tykhomyrov, T. V. Grinenko \\ Palladin Institute of Biochemistry, NAS of Ukraine \\ 9, Leontovycha Str., Kyiv, Ukraine, 01601 \\ chemikdd@mail.ru
}

\begin{abstract}
Aim. To study the vitronectin exposure on the platelet surface in the presence of two forms of the plasminogen molecule: Lys- and Glu-plasminogens. Methods. Research was conducted on human platelets. Aggregometry was used to check the platelet vitality and cell response towards thrombin. To evaluate the influence of different plasminogen forms on the platelet vitronectin exposure we used the method of flow cytometry. Results. It was found that incubation of resting platelets with Lys-plasminogen increased the amount of vitronectin-positive cells, but did not affect significantly their fluorescent intensity. Thrombin stimulation led to an increase in both: the number of vitronectin-positive platelets and the signal of fluorescence at least by two times. The Lys-plasminogen adding to the suspension of washed platelets followed by the thrombin stimulation enhanced the vitronectin exposure on the platelet surface and increased the amount of vitronectin-positive cells as compared to the isolated thrombin stimulation. Gluplasminogen had no effect on the vitronectin exposure in case of resting or stimulated platelets. Conclusions. Lys-plasminogen but not its Glu-form enhances the exposure of vitronectin on the platelet surface. We suggest that the binding of Lys-plasminogen to the surface platelet receptors may generate plasmin that leads to the activation of intracellular signaling cascade.
\end{abstract}

Keyw ord s: plasminogen, platelets, platelet secretion, vitronectin, flow cytometry.

\section{Introduction}

The platelet activation and following thrombus formation involve many adhesive proteins which are secreted from the platelet $\alpha$-granules including fibrinogen, von Willebrand factor, fibronectin and vitronectin $(\mathrm{Vn})$ [1]. However, it has been recently demonstrated that thrombus formation still occurs in the mice lacking both von Willebrand factor and fibrinogen [2] suggesting that other proteins such as fibronectin, thrombospondin and Vn may be able to mediate the platelet adhesion and aggregation [3]. Among these proteins, a special attention has been paid to $\mathrm{Vn}$, which plays a significant role in platelet physiology. It may regulate thrombosis and fibrinolysis through the interaction with integrins, plasminogen activator inhibitor-1 (PAI-1), collagen, and the urokinase receptor. In plasma, this protein circu- lates in an inactive folded form, in which most of its ligand-binding domains are hidden. Conversely, in the extracellular matrix and in blood platelets $\mathrm{Vn}$ is present in the activated multimeric form $[4,5]$. It was suggested that this adhesive protein is a thrombus stabilizer as it has a site (Arg-Gly-Asp) with the potential for binding to integrins $[6,7]$. However, the ideas about its exact role in thrombus formation are controversial. It was shown that the platelet-released $\mathrm{Vn}$ enhances the platelet aggregation, whereas the plasma $\mathrm{Vn}$ inhibits this process. It was reported that Vn has binding site to plasminogen, as monoclonal antibodies against the C-terminal portion of $\mathrm{Vn}$ inhibited plasminogen binding [8]. Recently we have shown that Lys-plasminogen but not its Glu-form inhibits the thrombin- and collagen-induced aggregation in the preparations of washed human platelets. In this study, we investigated the effects of two forms

(C) 2015 D. D. Zhernossekov et al.; Published by the Institute of Molecular Biology and Genetics, NAS of Ukraine on behalf of Biopolymers and Cell. This is an Open Access article distributed under the terms of the Creative Commons Attribution License (http://creativecommons.org/licenses/by/4.0/), which permits unrestricted reuse, distribution, and reproduction in any medium, provided the original work is properly cited 
of plasminogen on the vitronectin exposure on the surface of human platelets.

\section{Materials and Methods}

Human plasma and platelet preparations were obtained from blood of healthy volunteers $(n=5)$ as it was described before [9]. Research protocols were approved by the Ethical Committee of Palladin Institute of Biochemistry of NASU (from $3^{\text {rd }}$ of November 2014, protocol N 10).

Aggregometry was used to check platelet vitality and cell response towards thrombin. Platelet aggregation was measured by optical aggregometry (aggregometer «Solar AT-02», Belorussia). All assays were performed within 60-180 minutes after platelet collection. Experimental data were statistically analyzed using software «MS Excel» and «Agregometr 2.01». Thrombin (Sigma Aldrich, USA) at final concentration $1 \mathrm{NIH}$ unit/ml was used to stimulate platelets.

Glu-plasminogen was purified from fresh donor plasma and Lys-plasminogen was isolated from Cohn fraction II-III. Lysine-sepharose chromatography was used in both cases [10]. All preparations of plasminogen had no spontaneous plasmin activity.

To evaluate the influence of different plasminogen forms on Vn exposure by platelets the method of flow cytometry was used. The levels of exposed Vn were detected with use of respective antibodies to Vn (Sigma Aldrich, USA). The washed platelets $\left(10^{6}\right.$ cells) were transferred into $100 \mu \mathrm{l}$ of $20 \mathrm{mM}$ HEPES buffer, pH 6.8 containing $137 \mathrm{mM} \mathrm{NaCl}$, $4 \mathrm{mM} \mathrm{KCl}, 0.2 \mathrm{mM} \mathrm{MgCl}_{2}, 0.2 \%$ glucose and $0.2 \%$ bovine serum albumin (BSA). To perform investigations three groups of cells were used: resting platelets (control); platelets incubated with Glu- or Lys-plasminogen (time of exposure $3 \mathrm{~min}$ ); platelets treated with thrombin (5min), and platelets treated with thrombin after their preliminary incubation with Lys-plasminogen (3min). All procedures with platelets were carried out at $22-25^{\circ} \mathrm{C}$ to avoid platelet hyperactivation. Platelets shortly thereafter incubation with plasminogen or resting platelets (control group) were treated with anti-Vn antibodies. To carry out immunochemical detection of $\mathrm{Vn}$ we prepared the mixture of antibodies in
$0.05 \mathrm{M}$ sodium phosphate buffer (PBS), $\mathrm{pH} 7.4$ with $0.13 \mathrm{M} \mathrm{NaCl}$ and $1 \% \mathrm{BSA}$. Antibodies to $\mathrm{Vn}$ $(2 \mu \mathrm{g})$ were mixed with $100 \mu \mathrm{l}$ of PBS and secondary FITC-conjugated antibodies (Sigma Aldrich, USA) (final dilution 1:100). The mixture was incubated in the darkness at $4{ }^{\circ} \mathrm{C}$ for $15 \mathrm{~min}$. Platelets were incubated with the obtained mixture in the darkness at room temperature for $30 \mathrm{~min}$. As a control of non-specific antibody binding we used platelets which were incubated only with secondary FITC-conjugated antibodies. Non-bound antibodies were removed by double washing in PBS by centrifugation at $3,000 \mathrm{~g}$ for $3 \mathrm{~min}$ at $20{ }^{\circ} \mathrm{C}$. The obtained suspension of washed platelets was resuspended in $1 \mathrm{ml}$ of PBS and used for the investigation of Vn exposure at COULTER EPICS XL (Beckman Coulter, USA) equipped with argon laser, excitation $\lambda=488 \mathrm{~nm}$. Evaluation of Vn exposure on the platelet surface was done using two parameters: 1) percentage of Vn-positive platelets of the whole amount of investigated cells in the sample; 2) intensity of fluorescence, which was monitored by the channel FL1 $(515-535 \mathrm{~nm})$. To sort the

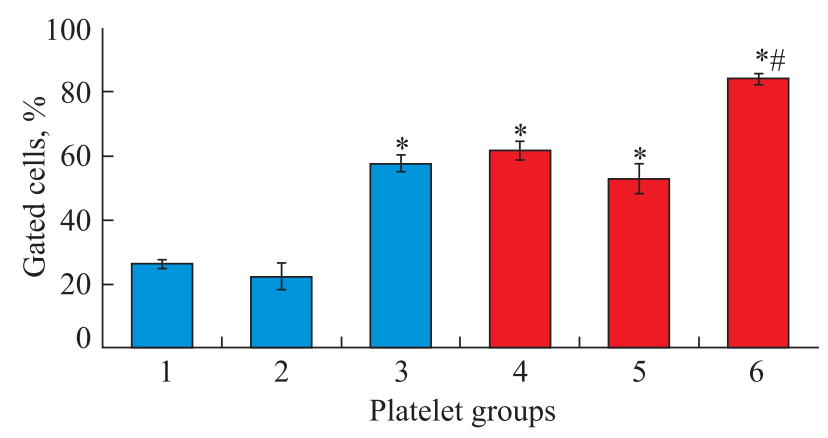

Fig. 1. Effects of Lys- and Glu-plasminogen on vitronectin exposure by intact and thrombin-stimulated platelets: 1 - resting platelets, 2 - resting platelets incubated with Glu-plasminogen, 3 resting platelets incubated with Lys-plasminogen, 4 - thrombinstimulated platelets, 5 - thrombin-stimulated platelets preliminary incubated with Glu-plasminogen, 6 - thrombin-stimulated platelets preliminary incubated with Lys-plasminogen. Blue columns resting platelets, red columns - thrombin-stimulated platelets. The concentrations of plasminogen forms and thrombin were $1.2 \mu \mathrm{M}$ and $1.0 \mathrm{NIH}$ units/ml respectively in all experiments. Difference in the compared groups is statistically significant $(p<0.05)$ : * compared to the group of 'resting platelets», \# - compared to the group of «thrombin-stimulated platelets» 


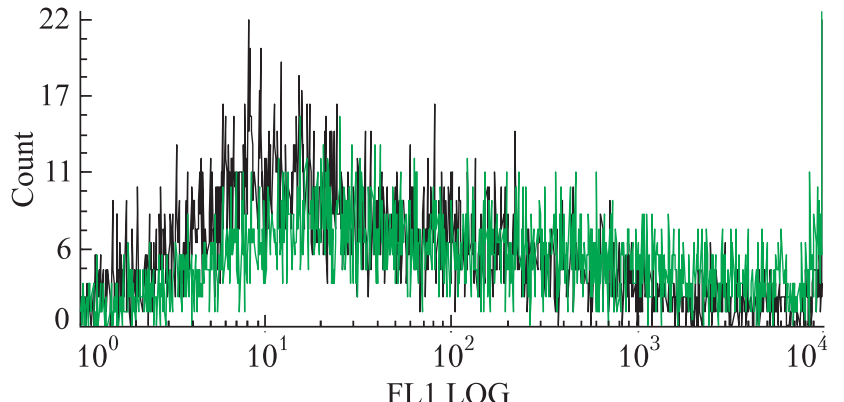

A

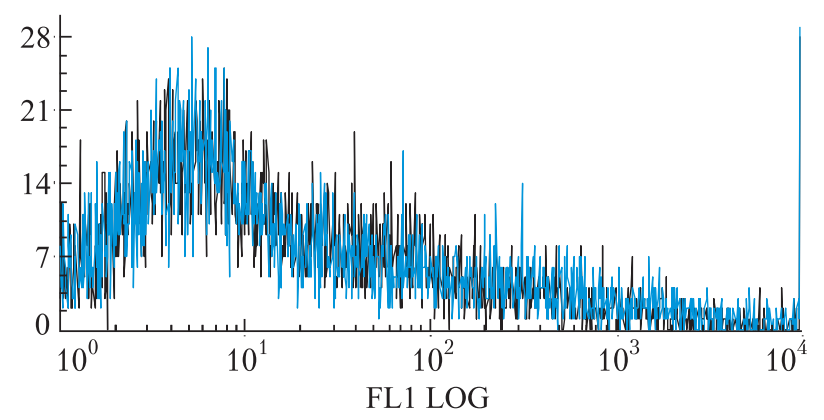

$B$

Fig. 2. Influence of Lys-plasminogen $(A)$ and Glu-plasminogen $(B)$ on vitronectin exposure by resting human platelets. Count - the amount of events, FL1 LOG - logarithm of fluorescence intensity with FITC. Black colour-resting platelets, green colour-platelets incubated with Lys-plasminogen, blue colour-platelets incubated with Glu-plasminogen
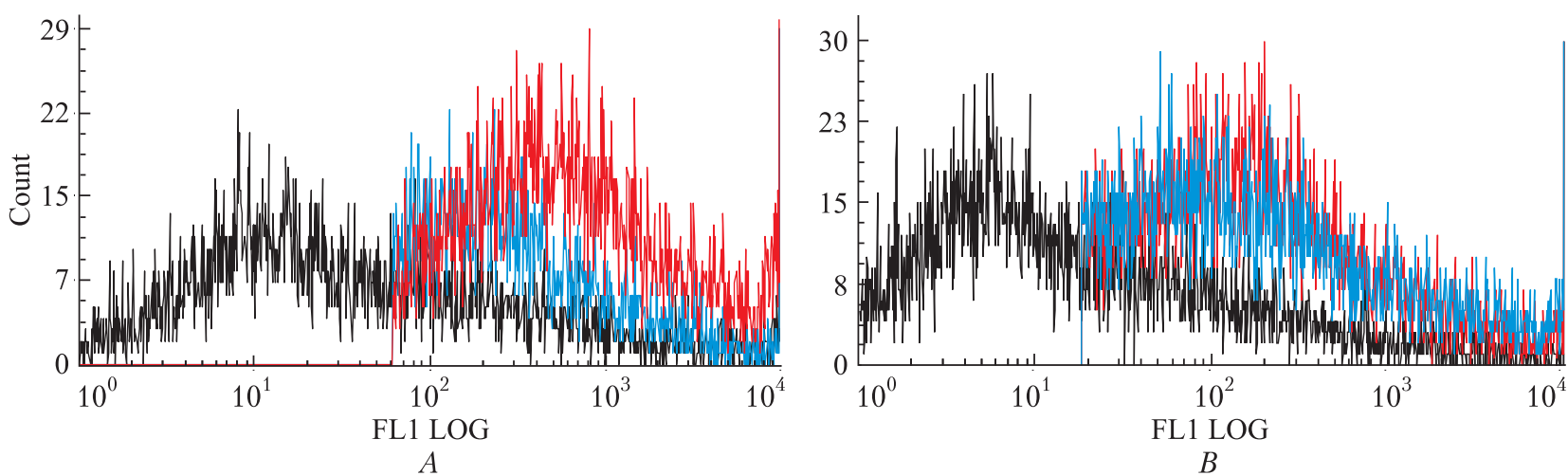

Fig. 3. Influence of Lys-plasminogen $(A)$ and Glu-plasminogen $(B)$ on vitronectin exposure by stimulated human platelets. Count - the amount of events, FL1 LOG - logarithm of fluorescence intensity with FITC. Black colour-resting platelets, blue colour-thrombin stimulated platelets, red colour-thrombin-stimulated platelets preliminary incubated with Lys-plaminogen $(A)$ or Glu-plasminogen $(B)$

platelets the corresponding gates were established. The changes in signal of fluorescence, which were observed in case of the impact of the investigated molecules, were defined according to the displacement of fluorescence curves relative to the marker, which limits the fluorescence curve of the intact platelets. The quantitative changes of the fluorescence were expressed in arbitrary units (AU) that mean the common logarithm according to scale Log FL1. To obtain statistically significant results at least 10 thousand events were analyzed.

The measurement of cytometric parameters in each group of cells was fulfilled in two parallels. Then, a mean value for the corresponding data obtained from all donors was calculated. The results were graphically presented using «FCS Express V3» (De Novo
Software, USA). The data were expressed as mean \pm SD. Statistical treatment of the results was made with Student's t-test, the difference was considered as significant with $\mathrm{p}<0.05$.

\section{Results and Discussion}

Using the flow cytometric analysis we determined the amount of Vn-positive cells and their fluorescence intensity. The presented data characterize the vitronectin exposure on the surface of resting and thrombinstimulated washed platelets (Fig. 1). The appearance of Vn-positive cells in the population of resting platelets can be due to the spontaneous activation of a part of cells taken in the experiment. It is recommended to use the population of platelets, the level of spontaneous activation of which does not exceed 50-55 \% [11] 
Lys-plasminogen stimulates vitronectin exposure on the platelet surface

that is in accordance with our data. When Lys-plasminogen was introduced into the incubation medium with intact platelets, an increase of vitronectin-positive cells was noted. The introduction of Glu-plasminogen had no effect (Fig. 1). It is known that the platelet affinity for Lys-plasminogen is higher as compared to Glu-plasminogen [12]. In its turn, the bound Lys-plasminogen may be considered as the preferable adhesive lygand for Vn, since the affinity of Lys-plasminogen towards vitronectin is significantly higher $\left(\mathrm{K}_{\mathrm{d}}=100 \mathrm{nM}\right.$ and $\mathrm{K}_{\mathrm{d}}=1 \mathrm{mM}$ respectively) [8].

We established that thrombin activation caused an increase of Vn-positive cells at least by 2 times as compared to the population of resting platelets. It is known that thrombin activation leads to secretion of alpha-granules, which contain vitronectin. According to the previous data, the activated platelets secreted highly adhesive multimeric Vn, half of which remained the platelet bound [13]. If Lys-plasminogen was added to the incubation medium prior to the thrombin activation, we noticed a significant increase of Vn-positive cells. In case of Glu-plasminogen, significant changes in the amount of Vn-positive cells were observed in comparison with the case of thrombin stimulation without prior plasminogen incubation. This difference may be also explained by different affinity of Glu- and Lys-plasminogens towards vitronectin.

The changes in intensity of the fluorescence signal of intact and thrombin-activated platelets have the same tendency as it was demonstrated for the quantitative rearrangement of the cells. The resting platelets incubated with Glu- or Lys-plasminogen do not reveal any significant changes of the fluorescence signal as compared to the control curve (Fig. 2). In case of the thrombin-activated platelets it was an essential shift of the peak of the fluorescence curve to the right of the control curve (Fig. 3), which agrees with the appearance of vitronectin-binding sites on the surface of thrombin-activated platelets. The preliminary incubation of stimulated platelets with Lys-plasminogen leads to the shift of the peak of fluorescence to the right (Fig. $3, A)$, whereas the incubation with Glu-plasminogen did not cause any changes as compared to the curve obtained for thrombin-stimulated platelets (Fig. 3, B).
The obtained results may be interesting consi-dering the role of plasminogen in cellular signaling. As it has been recently shown on peripheral monocytes and macrophages, the plasminogen binding to the annexin A2 S100 A10 may induce the plasmin generation, which results in the activation of intracellular signaling cascade and leads to a pro-inflammatory response [14]. It is quite pos-sible that the binding of Lys-plasminogen (which has open conformation and therefore is more readily converted into plasmin) to the platelet membrane may serve as an initial step of the cellular response. However, the further investigations should be done to prove this suggestion.

\section{Acknowledgments}

We gratefully acknowledge the skillful technical assistance of Mykhailo Guzik, Svitlana Diordieva and Vasyl Bilous.

\section{REFERENCES}

1. Broos K, Feys HB, De Meyer SF, Vanhoorelbeke K, Deckmyn $H$. Platelets at work in primary hemostasis. Blood Rev. 2011;25(4):155-67.

2. Ni H, Denis CV, Subbarao S, Degen JL, Sato TN, Hynes RO, Wagner $D D$. Persistence of platelet thrombus formation in arterioles of mice lacking both von Willebrand factor and fibrinogen. J Clin Invest. 2000;106(3):385-92.

3. Reheman A, Gross P, Yang H, Chen P, Allen D, Leytin V, Freedman J, Ni H. Vitronectin stabilizes thrombi and vessel occlusion but plays a dual role in platelet aggregation. J Thromb Haemost. 2005;3(5):875-83.

4. Stockmann A, Hess S, Declerck P, Timpl R, Preissner KT. Multimeric vitronectin. Identification and characterization of conformation-dependent self-association of the adhesive protein. J Biol Chem. 1993;268(30):22874-82.

5. Seiffert D, Schleef RR. Two functionally distinct pools of vitronectin $(\mathrm{Vn})$ in the blood circulation: identification of a heparin-binding competent population of $\mathrm{Vn}$ within platelet alpha-granules. Blood. 1996;88(2):552-60.

6. Asch E, Podack E. Vitronectin binds to activated human platelets and plays a role in platelet aggregation. J Clin Invest. 1990;85(5):1372-8.

7. Zhou A, Huntington JA, Pannu NS, Carrell RW, Read RJ. How vitronectin binds PAI-1 to modulate fibrinolysis and cell migration. Nat Struct Biol. 2003;10(7):541-4.

8. Kost C, Stüber W, Ehrlich HJ, Pannekoek H, Preissner KT. Mapping of binding sites for heparin, plasminogen activator inhibitor-1, and plasminogen to vitronectin's heparin-binding region reveals a novel vitronectin-dependent feedback 
mechanism for the control of plasmin formation. $J$ Biol Chem. 1992;267(17):12098-105.

9. Roka-Moya YM, Zhernossekov DD, Grinenko TV. Plasminogen/plasmin influence on platelet aggregation. Biopolym Cell. 2012;28(5):352-6.

10. Deutsch DG, Mertz ET. Plasminogen: purification from human plasma by affinity chromatography. Science. 1970;170 (3962):1095-6.

11. Leytin V, Mody M, Semple JW, Garvey B, Freedman J. Quantification of platelet activation status by analyzing P-selectin expression. Biochem Biophys Res Commun. 2000;273(2): 565-70.

12. Miles LA, Dahlberg CM, Plow EF. The cell-binding domains of plasminogen and their function in plasma. J Biol Chem. 1988;263(24):11928-34.

13. Parker CJ, Stone OL, White VF, Bernshaw NJ. Vitronectin (S protein) is associated with platelets. Br J Haematol. 1989; 71(2):245-52.

14. Godier A, Hunt BJ. Plasminogen receptors and their role in the pathogenesis of inflammatory, autoimmune and malignant disease. J Thromb Haemost. 2013;11(1):26-34.

\section{Lуs-плазминоген стимулирует экспонирование витронектина на поверхности тромбоцитов}

Д. Д. Жерносеков, Я. М. Рока-Мойя, А. А. Тихомиров, Т. В. Гриненко

Цель. Исследовать экспонирование витронектина на поверхности тромбоцитов в присутствии двух форм плазминогена: Lys- и Glu-плазминогена. Методы. Исследования проводили на тромбоцитах человека. Для проверки жизнеспособности тромбоцитов и клеточного ответа на тромбиновую стимуляцию использовали метод агрегометрии. Для оценки влияния разных форм плазминогена на экспонирование витронектина тромбоцитами использовали метод проточной цитометрии. Результаты. Было показано, что инкубация интактных тромбоцитов с Lys-плазминогеном приводила к увеличению количества витронектин-позитивных клеток, но не оказывала существенного влияния на их интенсивность флюоресценции. Стимуляция тромбином сопровождалась по меньшей мере двукратным увеличением как числа витронектин-позитивных тромбоцитов, так и интенсивности сигнала флюоресценции. Добавление Lys-плазминогена к суспензии отмытых тромбоцитов с последующей активацией тромбином усиливало экспонирование витронектина на тромбоцитарной поверхности и увеличивало количество витронектин-позитивных клеток по сравнению с изолиро- ванной стимуляцией агонистом. Glu-плазминоген не оказывал влияния на экспонирование витронектина в случае интактных или активированных тромбоцитов. Выводы. Lysплазминоген, но не его Glu-форма, усиливает экспонирование витронектина на поверхности тромбоцитов. Мы предполагаем, что связывание Lys-плазминогена с рецепторами на тромбоцитарной поверхности может способствовать образованию плазмина, который, в свою очередь, запускает процессы внутриклеточного сигналинга.

Кл юч е в ы е с л о в а: плазминоген, тромбоциты, тромбоцитарная секреция, витронектин, проточная цитометрия.

\section{Lys-плазміноген стимулюс експонування вітронектину на поверхні тромбоцитів}

Д. Д. Жерносєков, Я. М. Рока-Мойя, А. О. Тихомиров, Т. В. Гриненко

Мета. Дослідити експонування вітронектину на поверхні тромбоцитів за присутності двох форм плазміногену: Lysта Glu-плазміногену. Методи. Дослідження проводили на тромбоцитах людини. Для перевірки життєздатності клітин та клітинної відповіді на стимуляцію тромбіном використовували метод агрегометрії. Для оцінки впливу різних форм плазміногену на експонування вітронектину тромбоцитами було використано метод протокової цитометрії. Результати. Було показано, що інкубація інтактних тромбоцитів 3 Lysплазміногеном призводила до зростання кількості вітронектин-позитивних клітин, але суттєво не впливала на їх інтенсивність флуоресценції. Стимуляція тромбіном супроводжувалася принаймні двократним зростанням як кількості вітронектинпозитивних тромбоцитів, так і інтенсивності сигналу флуоресценції. Додавання Lys-плазміногену до суспензії відмитих тромбоцитів з наступною активацією тромбіном підсилювало експонування вітронектину на тромбоцитарній поверхні та збільшувало кількість вітронектин-позитивних клітин порівняно $з$ ізольованою стимуляцією агоністом. Glu-плазміноген не спричиняв впливу на експонування вітронектину в разі інтактних та активованих тромбоцитів. Висновки. Lysплазміноген, але не його Glu-форма, підсилює експонування вітронектину на поверхні тромбоцитів. Ми припускаємо, що зв'язування Lys-плазміногену з рецепторами тромбоцитарної поверхні може сприяти утворенню плазміну, який, в свою чергу, запускає процеси внутрішньоклітинного сигналінгу.

Кл юч о в і с л о в а: плазміноген, тромбоцити, тромбоцитарна секреція, вітронектин, протокова цитометрія.

Received 17.02.2015 